\title{
Downregulation of NKG2DLs by TGF- $\beta$ in human lung cancer cells
}

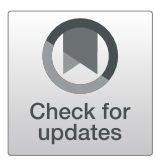

Young Shin Lee ${ }^{1 \dagger}$, Hojung Choi ${ }^{1 \dagger}$, Hae-Ryung Cho ${ }^{1,2}$, Woo-Chang Son ${ }^{3}$, You-Soo Park ${ }^{3}$, Chi-Dug Kang ${ }^{1}$ and Jaeho Bae 1,2* $^{1 *}$

\begin{abstract}
Background: Transforming growth factor beta (TGF- $\beta$ ) is a typical immuno-inhibitory cytokine and highly secreted by lung cancer cells. It was supposed that its immunosuppressive effects to NK cell might be related with the altered expression of activating and inhibitory molecules in lung cancer cells. In this study, we examined the expression of NKG2DLs, PD-L1 and PD-L2 in lung cancer cells after treatment of TGF- $\beta$ and a TGF- $\beta$ inhibitor, Galunisertib (LY2157299).

Results: TGF- $\beta$ reduced the level of surface proteins of five NKG2DLs without altered transcription levels in lung cancer cells. Galunisertib reversed the effect of TGF- $\beta$ on the expression of NKG2DLs. Since MMP inhibitors, MMPi III and MMP2 inhibitor I, restored the reduced expression of NKG2DLs after treatment of TGF- $\beta$, it was thought that TGF- $\beta$ induced the expression of MMP2 which facilitated the shedding of the NKG2DLs in cancer cells. However, the expression of PD-L1, L2 were not changed by treatment with TGF- $\beta$ or Galunisertib.

Conclusions: Therefore, inhibition of TGF- $\beta$ might reverse the immunosuppressive status on immune cells and restore NK cell mediated anticancer immune responses by upregulation of NKG2DLs in cancer cells.
\end{abstract}

Keywords: NKG2D ligands, Transforming growth factor beta, Matrix metalloproteinase

\section{Background}

Lung cancer is one of the most commonly diagnosed cancer and also the leading cause of cancer-associated mortality [1]. Even with more advanced chemotherapeutic agents and molecularly targeted drugs, the prognosis of this disease is still poor due to limited treatment efficiency $[2,3]$. Thus, given the higher recurrence and mortality rates, novel therapeutic strategies are warranted in order to improve the outcome of patients with lung cancer.

Natural-killer group 2, member D (NKG2D), is expressed by human NK cells and some kinds of T cells,

\footnotetext{
*Correspondence: biosole@pusan.ac.kr

${ }^{\dagger}$ Young Shin Lee and Hojung Choi contributed equally to this work.

'Department of Biochemistry, Pusan National University School of Medicine, Yangsan 50162, South Korea

${ }^{2}$ PNU BK21 Plus Biomedical Science Education Center, Pusan National University School of Medicine, Yangsan 50612, South Korea

Full list of author information is available at the end of the article
}

and transduces activating signals through binding to the NKG2DLs [4]. In this process, upregulation of NKG2DLs could activate the NK cells and evoke immune responses against the target cells [5]. Programmed cell death protein 1 (PD-1) is an immune checkpoint molecule and transduces inhibitory signaling which is expressed by mainly lymphocytes [6]. It binds to PD-L1 and PD-L2 on target cells, and decrease anti-cancer immune responses [7]. Since the activity of NK cells were modulated by the signaling balance derived from inhibitory and activating receptors, it was suggested that these NKG2DLs and PD-L1/2 might significantly influence on the killing ability of NK cells against cancer cells.

Among various immunomodulatory factors, transforming growth factor- $\beta$ (TGF- $\beta$ ) is a potent cytokine with immune suppressive effects including the negative regulation of lymphocyte proliferation, differentiation and survival [8] and TGF- $\beta$ inhibitor may attenuated the

(c) The Author(s). 2021 Open Access This article is licensed under a Creative Commons Attribution 4.0 International License, which permits use, sharing, adaptation, distribution and reproduction in any medium or format, as long as you give appropriate credit to the original author(s) and the source, provide a link to the Creative Commons licence, and indicate if changes were made. The images or other third party material in this article are included in the article's Creative Commons licence, unless indicated otherwise in a credit line to the material. If material is not included in the article's Creative Commons licence and your intended use is not permitted by statutory regulation or exceeds the permitted use, you will need to obtain permission directly from the copyright holder. To view a copy of this licence, visit http://creativecommons.org/licenses/by/4.0/ The Creative Commons Public Domain Dedication waiver (http://creativecommons.org/publicdomain/zero/1.0/) applies to the data made available in this article, unless otherwise stated in a credit line to the data. 
immune suppressive effects [9-11].. It was known that TGF- $\beta$ could inhibit the activity of natural killer (NK) cells and susceptibility of cancer cells to NK cells [12, 13]. In addition, TGF- $\beta$ regulates chemotaxis and the activity of other immune cells such as dendritic cells, macrophages, mast cells and granulocytes [8]. Therefore, TGF- $\beta$ is associated with tumor growth and malignant progression in various types of cancers [14-16]. It was known that promoted metastasis and invasion of cancer cells through TGF- $\beta$ signaling was associated with the increased expression and activity of matrix metalloproteinases (MMPs) [17, 18]. MMPs are zinc-dependent enzymes which play an important role in extracellular matrix degradation in the tumor microenvironment [19]. In addition, some kinds of metalloproteinase family facilitated the shedding and reduction of surface expression of NKG2DLs $[20,21]$. Since TGF- $\beta$ was highly secreted in lung cancer cells [22], it was supposed that TGF- $\beta$ might change the expression of signaling on NK cells through the altered expression of NKG2DLs and PD-L1/ L2. Therefore, high expression of MMPs might suppress NK cell-mediated anti-cancer immune responses.

In this study, it was evaluated that TGF- $\beta$ and TGF- $\beta$ inhibitor could altered expression of NKG2DLs and PDL1/L2. In addition, a possible modulating molecule, MMP2 could mediate the expression of NKGD2DLs through TGF- $\beta$ signaling. Finally, it was investigated that TGF- $\beta$ inhibitor could enhance the susceptibility of lung cancer cells to NK cell.

\section{Results}

TGF- $\beta$ decreased the surface expression of NKG2DLs in lung cancer cells

The surface expression of NKG2DLs in lung cancer cells was analyzed using flow cytometry after treatment with TGF- $\beta$. The surface expression levels of five NKG2DLs including ULBP1 and ULBP2 were decreased by - 0.3 -fold after treatment with $20 \mathrm{ng} / \mathrm{ml}$ TGF- $\beta$. ULBP1 was supressed at $10 \mathrm{ng} / \mathrm{ml}$ TGF- $\beta$ in NCI-H23 cells (Fig. 1A). The surface expression levels of ULBP1, ULBP2 and ULBP3 were decreased by 0.3fold, 0.4-fold and 0.3-fold, respectively, after treatment with $10 \mathrm{ng} / \mathrm{ml}$ TGF- $\beta$ in SW-900 cells. The reduction of these three kinds of NKG2DLs was more profound. (Fig. 1B). MICA and ULBP1/2/3 were decreased by 0.3-fold, 0.1 -fold, 0.2 -fold and 0.3-fold, respectively, after treatment with $20 \mathrm{ng} / \mathrm{ml}$ TGF- $\beta$. ULBP3 was supressed at $10 \mathrm{ng} / \mathrm{ml}$ TGF- $\beta$ in A549 cells (Fig. 1C). ULBP3in NCI-H23 cells and MICA in SW-900 cells were not detected and marked by ND. These results suggest that TGF- $\beta$ could affect the surface expression of NKG2DLs in lung cancer cells. The kinds of NKG2DLs which were decreased after treatment with TGF- $\beta$ were different depending on the cell lines.

\section{Galunisertib reversed the surface expression of NKG2DLs} in lung cancer cells

To block the role of TGF- $\beta$, three kinds of lung cancer cells were treated with a TGF- $\beta$ inhibitor, Galunisertib, and the surface expression of five NKG2DLs was analyzed by flow cytometry. Galunisertib reversed the effects of TGF-b in surface expression of NKG2DLs in lung cancer cells. In NCI-H23 cells, the surface expression of MICA, ULBP1 and ULBP2 was increased by TGF- $\beta$ inhibitor (Fig. 2A). In SW-900 cells, the surface expression of MICB and ULBP1/2/3 was increased by TGF- $\beta$ inhibitor (Fig. 2B). In A549 cells, five kinds of NKG2DLs were reversed by TGF- $\beta$ inhibitor (Fig. 2 C). As results from Figs. 1 and 2, it was supposed that TGF- $\beta$ signaling might regulate the expression of NKG2D ligands in lung cancer cells.

\section{Combined treatment of TGF- $\beta$ and Galunisertib did not alter the transcription levels of NKG2DLs in lung cancer cells}

The transcription levels of NKG2DLs were analyzed by multiplex RT-PCR. When treated with TGF- $\beta$ and Galunisertib, the transcription levels of NKG2DLs in three lung cancer cells were not changed significantly (Fig. 3). Therefore, TGF- $\beta$ signaling may modulate the expression of NKG2DLs at post-transcriptional level without significant changes of transcription.

\section{Treatment with TGF- $\beta$ and Galunisertib altered the expression of MMP2}

Since previous results showed that TGF- $\beta$ regulates the surface expression of NKG2D s, it was needed to investigate how TGF- $\beta$ regulates the expression of NKG2DLs. It was known that many kinds of MMPs were induced by TGF- $\beta$ and some kinds of MMPs such as MMP2, MMP9 and MMP14 could reduce the surface expression of NKG2DLs [19, 21, 23, 24]. Therefore, it was supposed that the surface expression of NKG2DLs might be regulated by the role MMPs induced by TGF- $\beta$. In these studies, we investigated the changes of MMPs through TGF- $\beta$ signaling which were related with the reduction of surface NKG2DLs.

The transcription of MMP2 was significantly increased by treatment with TGF- $\beta$ in three lung cancer cells (Figs. 4 and 5). The other MMPs including MMP1, MMP9 and MMP14 were differentially changed in three lung cancer cells depending on specific cell types. MMP1 was increased in SW-900 cells and A549 cells by treatment with TGF- $\beta 10 \mathrm{ng} / \mathrm{ml}$ and $20 \mathrm{ng} / \mathrm{ml}$ (Fig. 4B and C). MMP9 in NCI-H23 cells, and MMP1 in SW-900 cells were also increased by treatment with TGF- $\beta$ (Fig. $4 \mathrm{~A}$ and $\mathrm{B})$. When TGF- $\beta$ and Galunisertib were cotreated, increased MMPs were reversed except MMP1 in SW-900 and A549. It was demonstrated that TGF- $\beta$ 

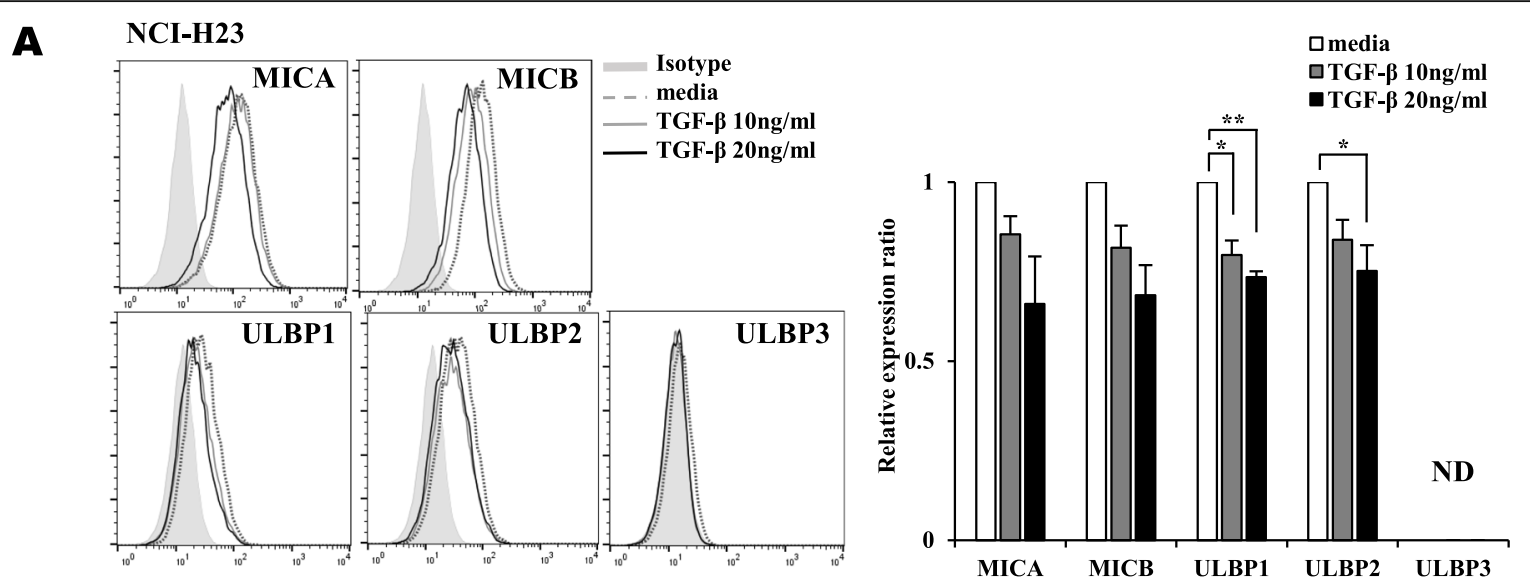

B
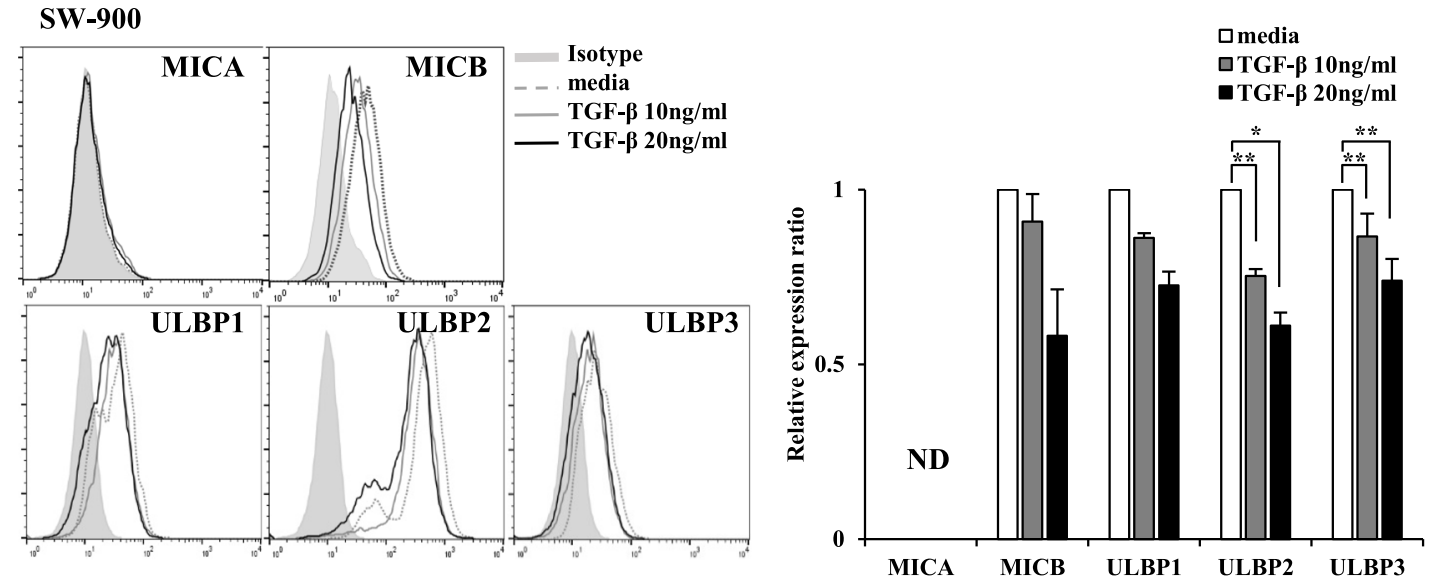

C
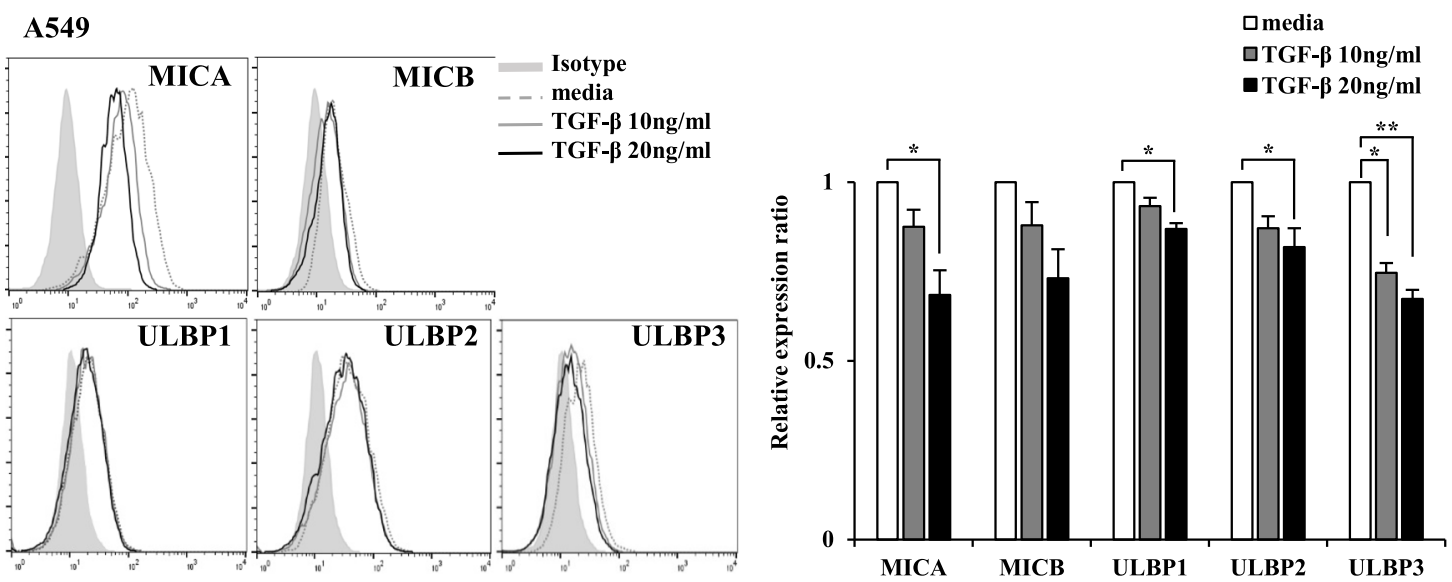

Fig. 1 Decrease surface expression levels of some kinds of NKG2DLs by treatment with TGF- $\beta$. The surface expression levels of NKG2DLs were showed as histograms and graphs in (A) NCl-H23, (B) SW-900 and (C) A549 lung cancer cells, which were treated with TGF- $\beta$ (10 ng/ml, 20 ng/ $\mathrm{ml}$ ) for $24 \mathrm{~h}$. A representative data was shown. The relative expression ratios were calculated from mean fluorescence intensities (MFI) of treated cells compared to those of control cells. Filled gray, dotted gray, gray and black lines represent isotype, media control, TGF- $\beta$ 10 ng/ml treatment and TGF- $\beta 20 \mathrm{ng} / \mathrm{ml}$ treatment, respectively. The experiments were performed three times. $\left(p<0.05, * ; p<0.01,{ }^{* *}\right)$ 


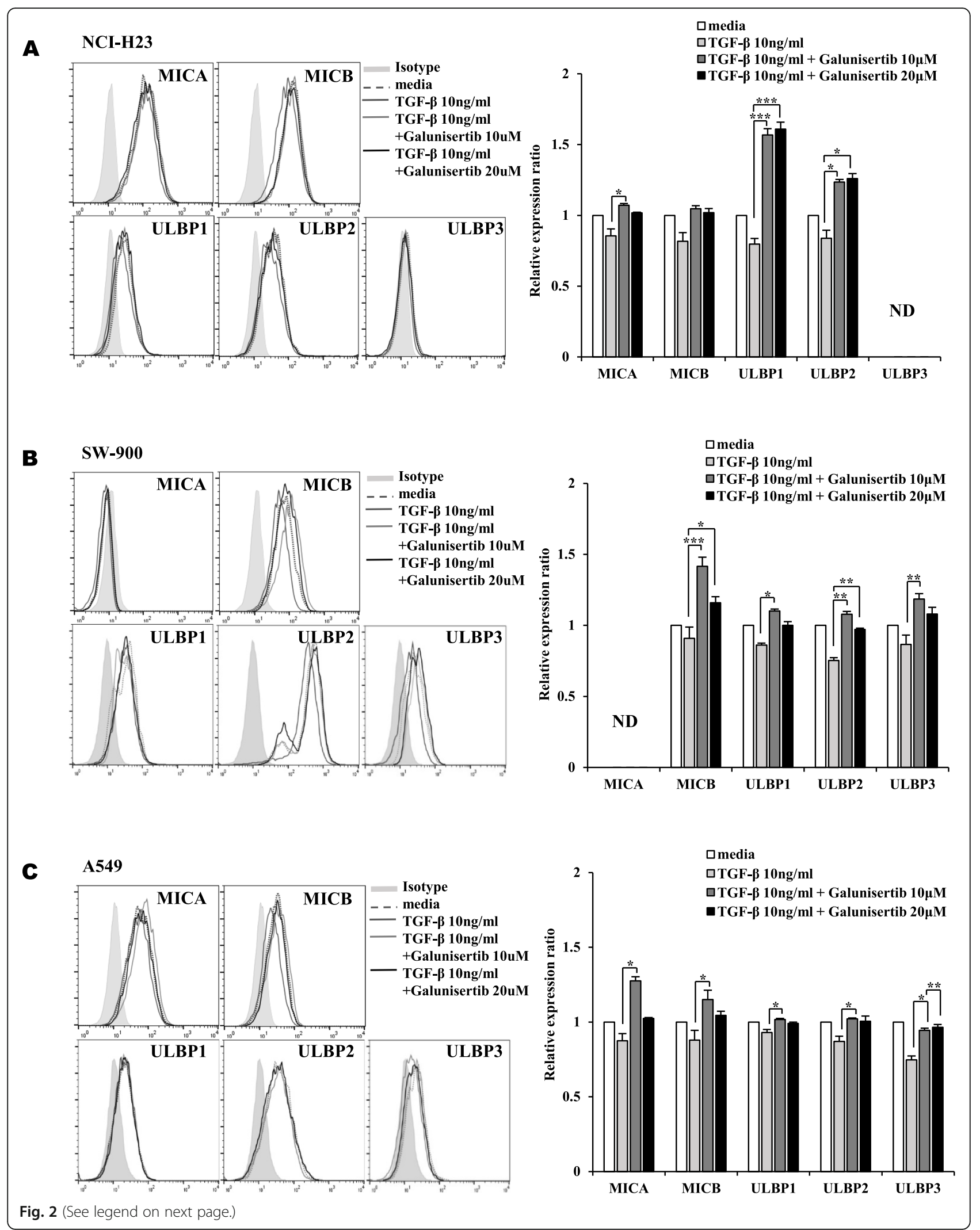


(See figure on previous page.)

Fig. 2 Restored surface expression levels of NKG2DLs by blocking of TGF- $\beta$ signaling. The surface expression levels of NKG2DLs were analyzed using flow cytometry in (A) NCl-H23, (B) SW-900 and (C) A549 lung cancer cells. The lung cancer cells were treated with TGF- $\beta$ (10 ng/ml) and followed by Galunisertib $(10 \mu \mathrm{M}, 20 \mu \mathrm{M})$ for $24 \mathrm{~h}$. The relative expression ratios were calculated from mean fluorescence intensities (MFI) of treated cells compared to those of control cells. Filled gray, dotted gray, dark gray, light gray and black lines represent isotype, media control, TGF- $\beta 10$ $\mathrm{ng} / \mathrm{ml}$ treatment, TGF- $\beta 10 \mathrm{ng} / \mathrm{ml}$ with Galunisertib $10 \mu \mathrm{M}$ treatment and TGF- $\beta 10 \mathrm{ng} / \mathrm{ml}$ with Galunisertib $20 \mu \mathrm{M}$ treatment, respectively. The experiments were performed three times. $\left(p<0.05,{ }^{*} ; p<0.01,{ }^{* *} ; p<0.001,{ }^{* *}\right)$

induced the expression of MMP2 and Galunisertib reversed the changes of MMPs in three kinds of lung cancer cells (Fig. 4). Interestingly, the expression of MMP1 in NCI-H23 cells was decreased by treatment with TGF$\beta$ (Fig. 4A). MMP14 in NCI-H23 cells, MMP9 in SW900 cells, and MMP9 and MMP14 in A549 cells were not detected and marked as ND.

When the protein levels of MMP2 were measured, TGF- $\beta$ induced the expression of MMP2 and Galunisertib reversed its level at three kinds of lung cancer cells (Fig. 5). It was supposed that high level of MMP2 might reduce the surface NKG2DLs.

\section{MMP inhibitors increased the surface expression of NKG2DLs in lung cancer cells}

To investigated the role of MMPs through TGF- $\beta$ signaling, three lung cancer cells treated with MMP inhibitor III (MMPi III), and MMP2 inhibitor I (MMP2i I) which are a broad spectrum MMP inhibitor and MMP2 specific inhibitor, respectively. Both MMP inhibitors dramatically increased NKG2DLs except ULBP3 in NCI-H23 cells and MICA in SW-900 which was not detected any condition (Fig. 6). When MMP inhibitors were co-treated with TGF- $\beta$, the suppression of NKG2DLs was blocked partially in three lung cancer cell lines. Although it was treated with MMP2 inhibitor, the expression of NKG2DLs showed a tendency to decrease with treatment of TGF- $\beta$. It means that TGF- $\beta$ has another mechanism to reduce the expression of NKG2DLs besides the induction of MMP2. In previous studies, it can be suggested that there are two possible mechanisms which are upregulation of proteasomal activity and induction of miRNA [25-27].

\section{Galunisertib reversed susceptibility of lung cancer cells to NK cells}

Since TGF- $\beta$ downregulated the expression of NKG2DLs in lung cancer cells, it might repress the susceptibility of lung cancer cells to NK-92 cells. By treatment of TGFbeta, NK cell-mediated cytotoxicity was suppressed. The susceptibility of lung cancer cells to NK-92 cells was reversed by co-treatment of Galunisertib in three lung cancer cells (Fig. 7).

\section{Discussion}

TGF- $\beta$ signaling plays a crucial role in various tumor microenvironments and performs a variety of functions such as cell proliferation, differentiation, apoptosis, extracellular matrix reorganization and epithelialmesenchymal transition (EMT) [28]. In addition, TGF- $\beta$ is a cytokine which has immune suppressive effects [8]. In previous studies, TGF- $\beta$ directly suppressed cytotoxic $\mathrm{T}$ lymphocyte and induced regulatory $\mathrm{T}$ cells. TGF- $\beta$ also inhibited NK cell and B cell proliferation and functions [29-33]. Therefore, it is thought that the inhibition of TGF- $\beta$ is important to restore function of NK cells and suppress the cancer progression.

NKG2DLs in cancer cells are known to promote immune responses by binding to NKG2D in immune effector cells such as some kinds of T cells and NK cells $[5,34]$. Although it was known that TGF- $\beta$ could inhibit the activity of NK cells and the susceptibility of cancer cells to NK cells [35], the mechanism by which TGF- $\beta$ affect the expression of NKG2DLs in lung cancer cells has not been identified. We supposed that TGF- $\beta$ might affect the expression of activating ligands such as NKG2DLs and inhibitory ligands such as PD-L1/L2 in lung cancer cells. In this study, it was investigated whether NKG2DLs and PD-L1/L2 in lung cancer cells could be regulated by TGF- $\beta$ signaling. As a result, TGF- $\beta$ and a TGF- $\beta$ inhibitor, Galunisertib, could regulate the surface expression of NKG2DLs in lung cancer cells. The transcription levels of NKG2DLs were not related with TGF- $\beta$ signaling. Although the exact mechanism of TGF- $\beta$ in regulation of NKG2DLs is not clear, it was thought that the main regulation step is posttranscriptional level.

There are many reports that TGF- $\beta$ stimulates the expression of variety of MMPs in mammary carcinoma, squamous cell carcinoma (SSC), melanoma and other types of cancer cells [17, 36-38]. Since inhibition of MMPs could increase the expression levels of NKG2DLs $[19,38,39]$, it was suggested that MMPs mediated the regulation of NKG2DLs through TGF- $\beta$ signaling.

In this study, it was demonstrated that the mRNA and protein levels of MMP2 were increased by treatment with TGF- $\beta$ and reversed by co-treatment with Galunisertib. The inhibition of MMPs by treatment with MMPi III and MMP2i I upregulated the surface expression of NKG2DLs which were suppressed by TGF- $\beta$. These 
A NCI-H23
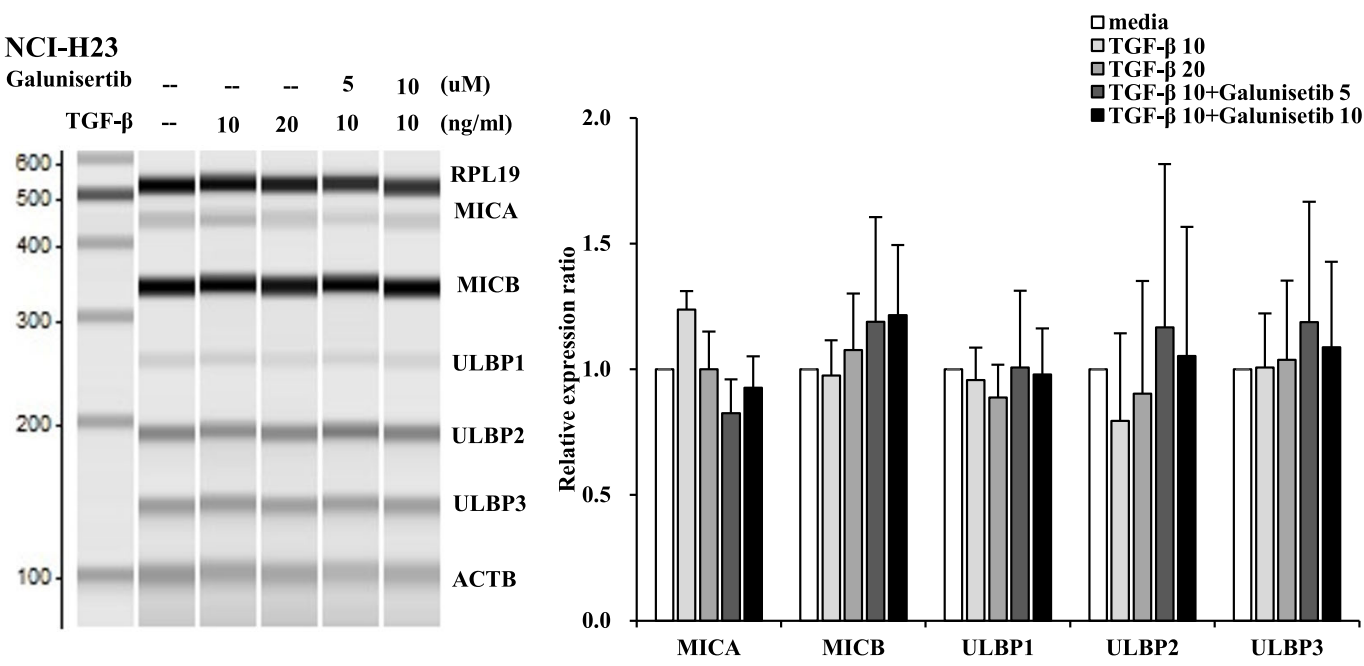

B SW-900
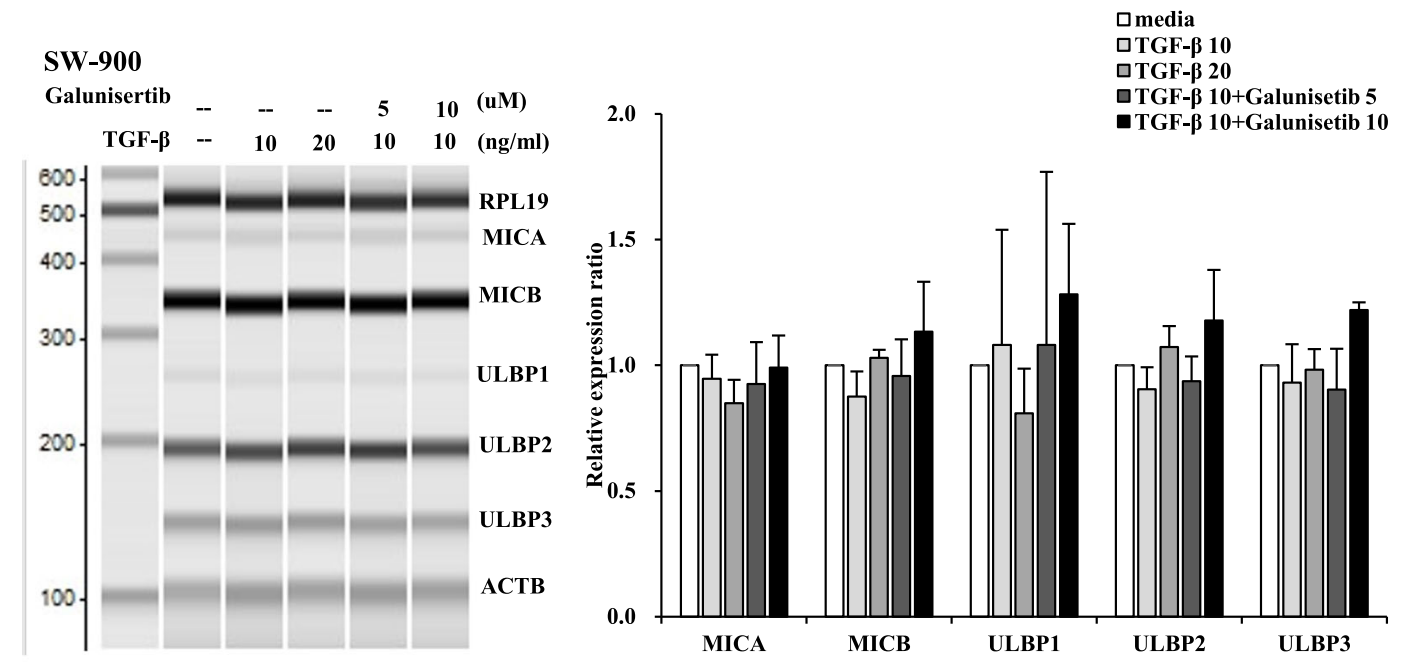

\section{C}

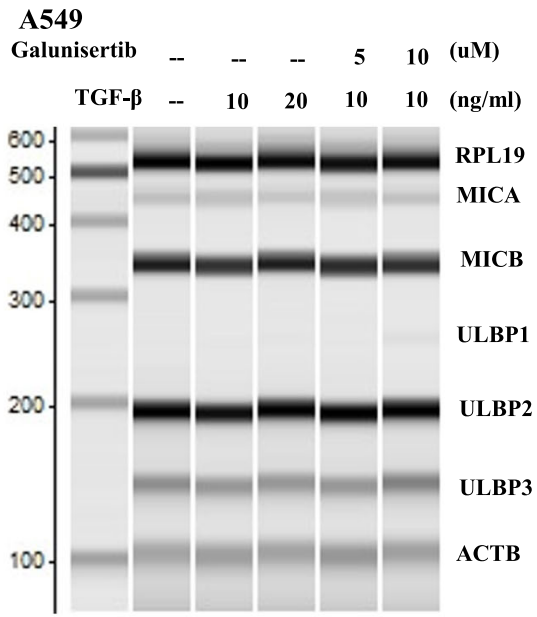

Fig. 3 (See legend on next page.)

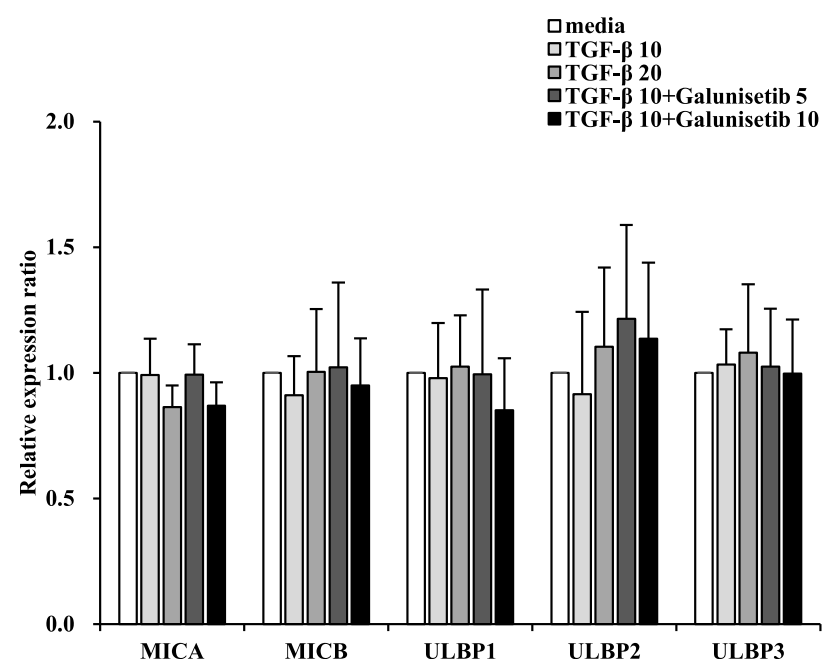


(See figure on previous page.)

Fig. 3 No significant the changes of transcription of NKG2DLs by combined treatment of TGF- $\beta$ and Galunisertib in lung cancer cells. The transcription levels of NKG2DLs were analyzed in (A) NCI-H23, (B) SW-900 and (C) A549 lung cancer cells by multiplex RT-PCR. The flung cancer cells were treated with TGF- $\beta$ (10 and $20 \mathrm{ng} / \mathrm{ml})$ and Galunisertib $(5$ and $10 \mu \mathrm{M})$ for $18 \mathrm{~h}$. The PCR products were separated and quantified by MultiNA. All experiments were done in triplicate. Changes of transcriptions were normalized by ACTB and presented as the mean fold changes compared to media treated groups. The experiments were performed three times

results suggest that MMP2 might be a main regulator in the expression of NKG2DLs through TGF- $\beta$ signaling. TGF- $\beta$ induced the expression of MMP2 commonly in three lung cancer cells and other MMPs were regulated differentially depends on cell types.

It has been suggested that metalloproteinase family including MMPs and ADAMs could increase the level of soluble NKG2DLs and decrease the level of surface NKG2DLs simultaneously [20,21]. It was also reported that MMP2 in renal carcinoma cells, MMP9 and MMP14 in osteosarcoma cells could increase soluble MICA [23, 24, 40, 41] and MMP9 specific inhibitor could increase MICA/B and ULBP2 in some kinds of gastric cancer cells [19].

NK cells are cytotoxic against many cancer cells and the cytotoxicity of NK cells is regulated by the signal transduction balance between activation and inhibition receptors [34, 42-45]. Thus, beside of the induction of activating ligands such as NKG2DLs in cancer cells, the reduction of inhibition ligands is necessary to enhanced NK cell mediated anticancer responses. It was investigated whether a kind of inhibition ligands, PD-L1 and PD-L2, in cancer cells could be regulated by TGF- $\beta$ signaling. In result, TGF- $\beta$ signaling did not influence on the expression of PD-L1 and PD-L2 (Fig. S2).

Many kinds of cancer overexpress TGF- $\beta$ and high levels of TGF- $\beta$ in cancer patients frequently associated with poor prognosis. Recently anti TGF- $\beta$ therapy has been tried to control cancer progression. We supposed that anti TGF- $\beta$ therapy might inhibit cancer progression as well as restore anti-cancer immune responses through reactivation of immune cells and enhance the susceptibility of cancer cells.

\section{Conclusion}

Stimulation of TGF- $\beta$ signaling could decrease the expression of NKG2DLs in lung cancer cells which might be related with increased expression of MMP2. Therefore, inhibition of TGF- $\beta$ might block the immunosuppressive effects on immune cells and restore NK cell mediated anticancer immune responses by upregulation of NKG2DLs in cancer cells.

\section{Methods}

\section{Cell lines and reagents}

Three human lung cancer cell lines were used in this study including A549, NCI-H23, and SW-900. These cell lines were obtained from the Korean Cell Line Bank (Seoul, South Korea) and were maintained in RPMI1640 medium supplemented with $10 \%$ fetal bovine serum (Gibco, Grand Island, NY, USA), $2 \mathrm{mM} \mathrm{L-glutam-}$ ine, $100 \mathrm{mg} / \mathrm{mL}$ streptomycin, and $100 \mathrm{U} / \mathrm{mL}$ penicillin. All cell lines were cultured at $37^{\circ} \mathrm{C}$ in a humidified atmosphere containing $5 \% \mathrm{CO}_{2}$ [46].

Recombinant human TGF- $\beta$ was purchased from R\&D systems, Inc. (Minneapolise, MN, USA), dissolved at $20 \mu \mathrm{g} / \mathrm{ml}$ in sterile $4 \mathrm{mM} \mathrm{HCl}$ containing $1 \mathrm{mg} / \mathrm{ml}$ bovine serum albumin and used at 10 and $20 \mathrm{ng} / \mathrm{ml}$ doses. Galunisertib were purchased from Selleckchem (Houston, TX, USA), dissolved at $10 \mathrm{mM}$ in dimethyl sulfoxide and used at 5, 10, and $20 \mu \mathrm{M}$ doses. MMP Inhibitor III, a pan inhibitor of MMPs, and MMP2 inhibitor I, a specific inhibitor of MMP2, were purchased from Calbiochem (Merck KGaA, Darmstadt, Germany) and dissolved at $10 \mathrm{mM}$ in dimethyl sulfoxide and used at $10 \mu \mathrm{M}$ dose. $\backslash$.

\section{Total RNA extraction and multiplex reverse transcription (RT)-PCR}

Total RNA extraction and qPCR were performed as described by previous methods [47]. Briefly, total RNA was extracted from the cells using the RNeasy ${ }^{\circ}$ Mini kit (Qiagen, Hilden, Germany), according to the manufacturer's instructions. cDNA was synthesized from $1 \mu \mathrm{g}$ extracted total RNA, using $100 \mathrm{pmol}$ random primers (Takara Bio Inc., Otsu, Japan) and 100 U M-MLV reverse transcriptase (Promega Corporation, Madison, WI, USA). The resulting cDNA was used in the PCR reaction, which was performed using the QIAGEN Multiplex PCR kit (Qiagen). Numerous primer pairs were used to investigate the mRNA expression levels of NKG2DLs [47]: MHC class-I polypeptide-related chain proteins MICA and MICB, UL16 binding proteins (ULBP)1-3, MMPS: of matrix metalloproteinases (MMP)1, 2, 9 and 14; PD-1 ligands: Programmed death-ligand 1 (PD-L1), Programmed cell death 1 ligand 2 (PD-L2) (Bioneer Corporation, Daejeon, South Korea). $\beta$-actin and ribosomal protein L19 were used as the loading control and degradation marker, respectively. The PCR products were separated and quantified by MultiNA (Shimadzu, Tokyo, Japan).

\section{Flow cytometry}

To determine the surface NKG2DLs on cancer cells, the cells were incubated with mouse anti-MICA, 

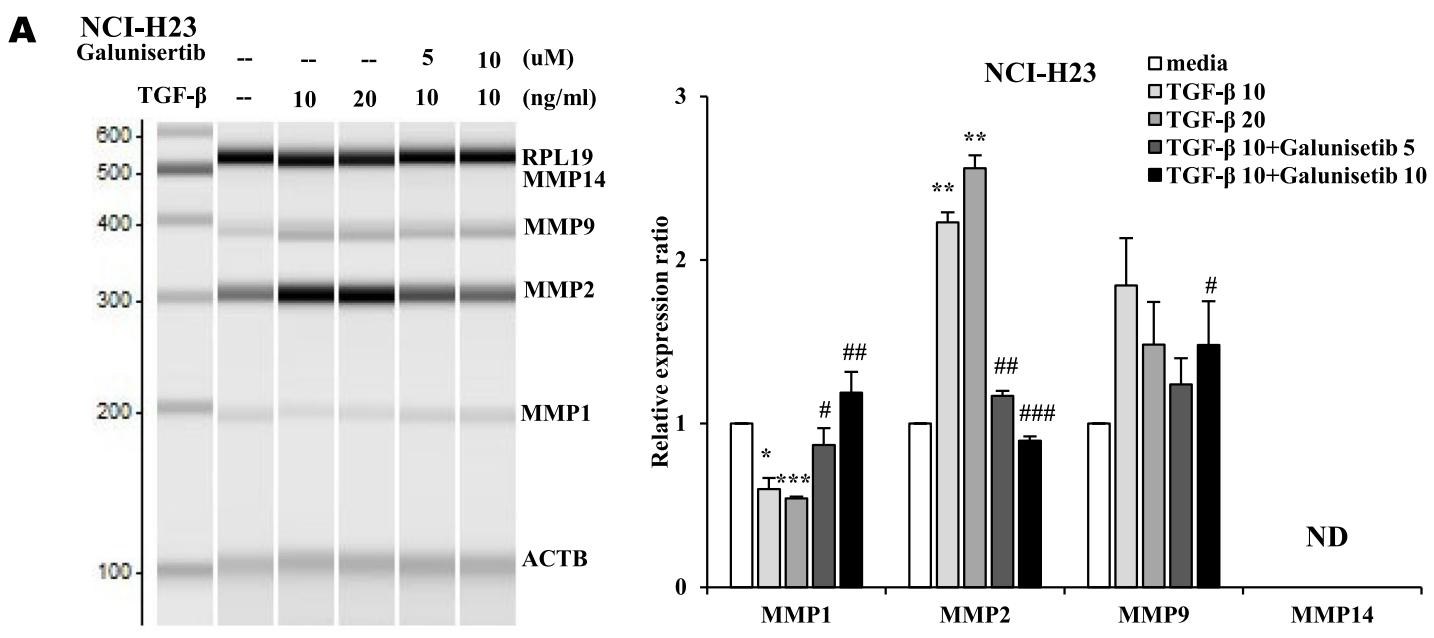

B SW-900

$\begin{array}{lllllll}\text { Galunisertib } & -- & -- & -- & 5 & 10 & \text { (uM) }\end{array}$
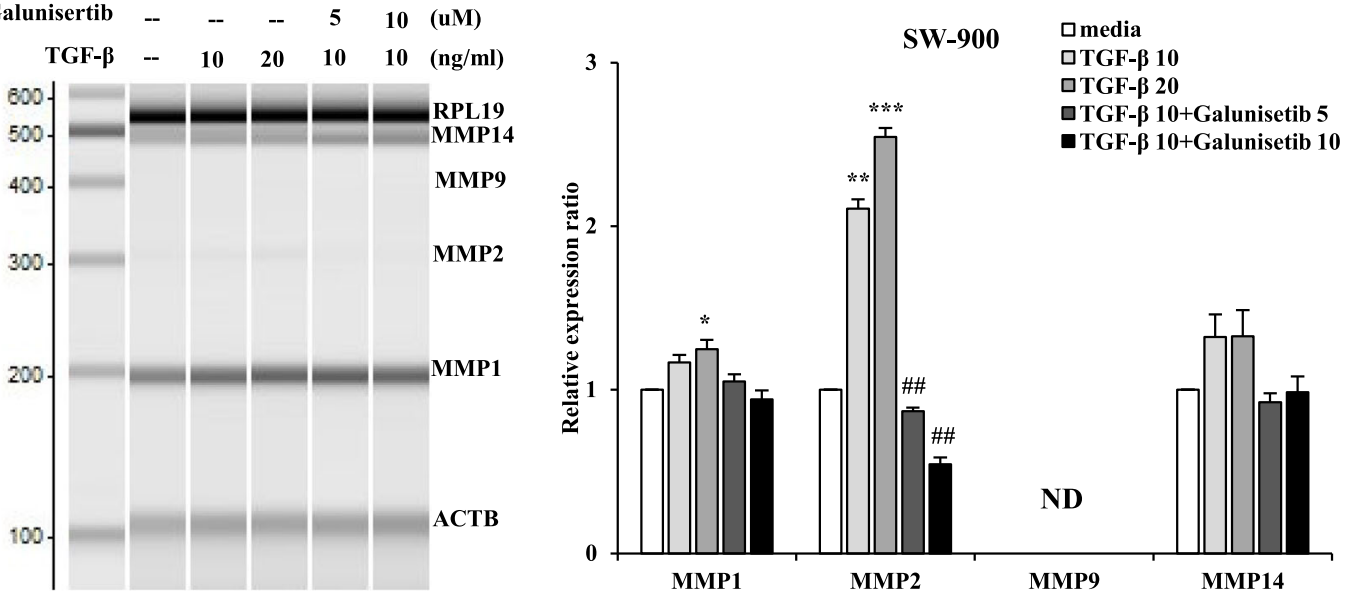

C $\mathbf{A 5 4 9}$
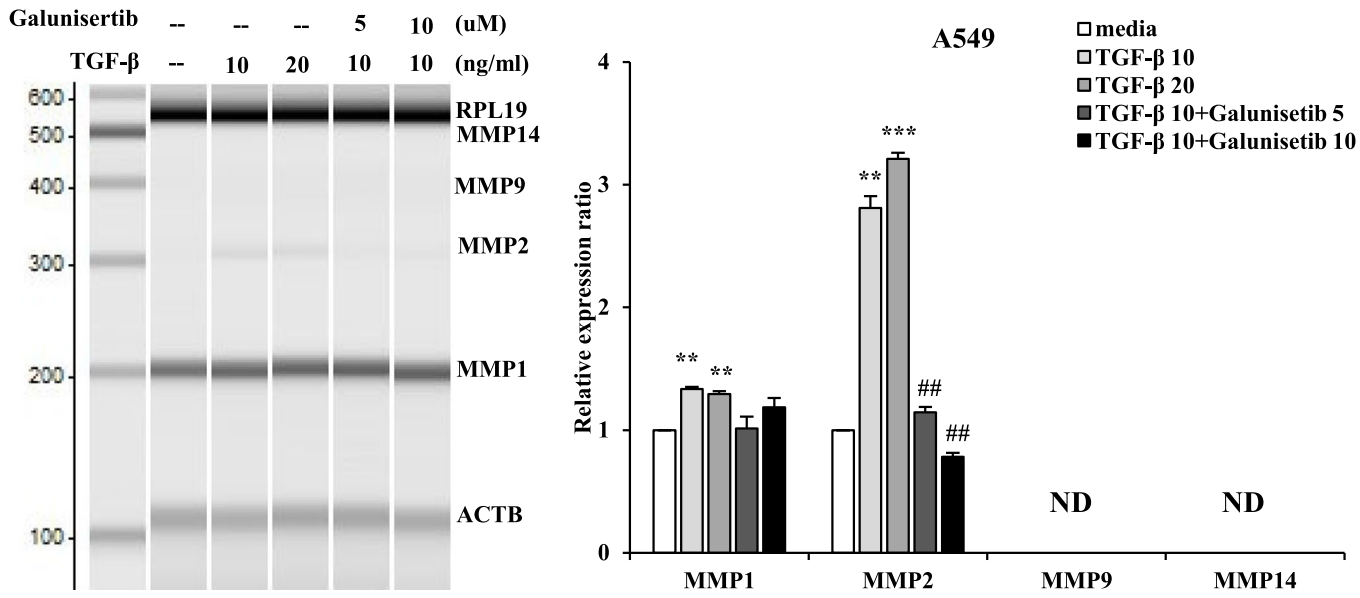

Fig. 4 (See legend on next page.) 
(See figure on previous page.)

Fig. 4 The transcriptions of MMPs were regulated by treatment with TGF- $\beta$ and Galunisertib. The transcription levels of MMPs were analyzed in (A) NCl-H23, (B) SW-900 and (C) A549 lung cancer cells by multiplex RT-PCR. Lung cancer cells were treated with TGF- $\beta$ (10 and 20 ng/ml) and Galunisertib $(5$ and $10 \mu \mathrm{M})$ for $18 \mathrm{~h}$. The PCR products were separated and quantified by MultiNA. All experiments were done in triplicate. The changes of transcripts were compared to media treated groups after treatment with TGF- $\beta$ without Galunisertib. The changes of transcription levels were compared to TGF- $\beta$ treated groups after combined treatment with TGF- $\beta$ with Galunisertib. The experiments were performed three

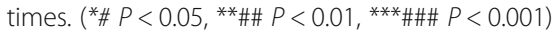

anti-MICB, anti-ULBP1-3 (R\&D systems, Minneapolis, MN, USA), which were NKG2D ligand-specific monoclonal antibodies (mAbs) or the corresponding isotype controls at $1 \mu \mathrm{g} / 100 \mu \mathrm{l}$ followed by incubation with PE goat anti-mouse Ig (BD Phamingen Inc., San Diego, CA, USA). The analysis was performed on the BD FACSCANTO II (Becton Dickinson and Company, Franklin Lakes, NJ, USA) using FlowJo software (BD Biosciences, Franklin Lakes, NJ, USA) and the cell surface expression was quantified by the value of the mean fluorescence intensities (MFI) obtained with the specific mAbs [48].

\section{Western blotting analysis}

Western blotting analysis was performed to evaluate the expression of MMP. The cells were washed twice with cold phosphate buffered saline and lysed. Equal amounts of cell extracts were resolved by 4-20\% SDS-PAGE and analyzed by Western blot. The separated proteins were transferred onto nitrocellulose membranes (HybondECL, GE healthcare, Buckinghamshire, UK). In the next step, the membranes were blocked with $4 \%$ nonfat milk in Tris buffered saline containing $0.1 \%$ Tween 20 at room temperature. Proteins of interest were then detected with the primary antibodies (MMP 1 and 2: Cell

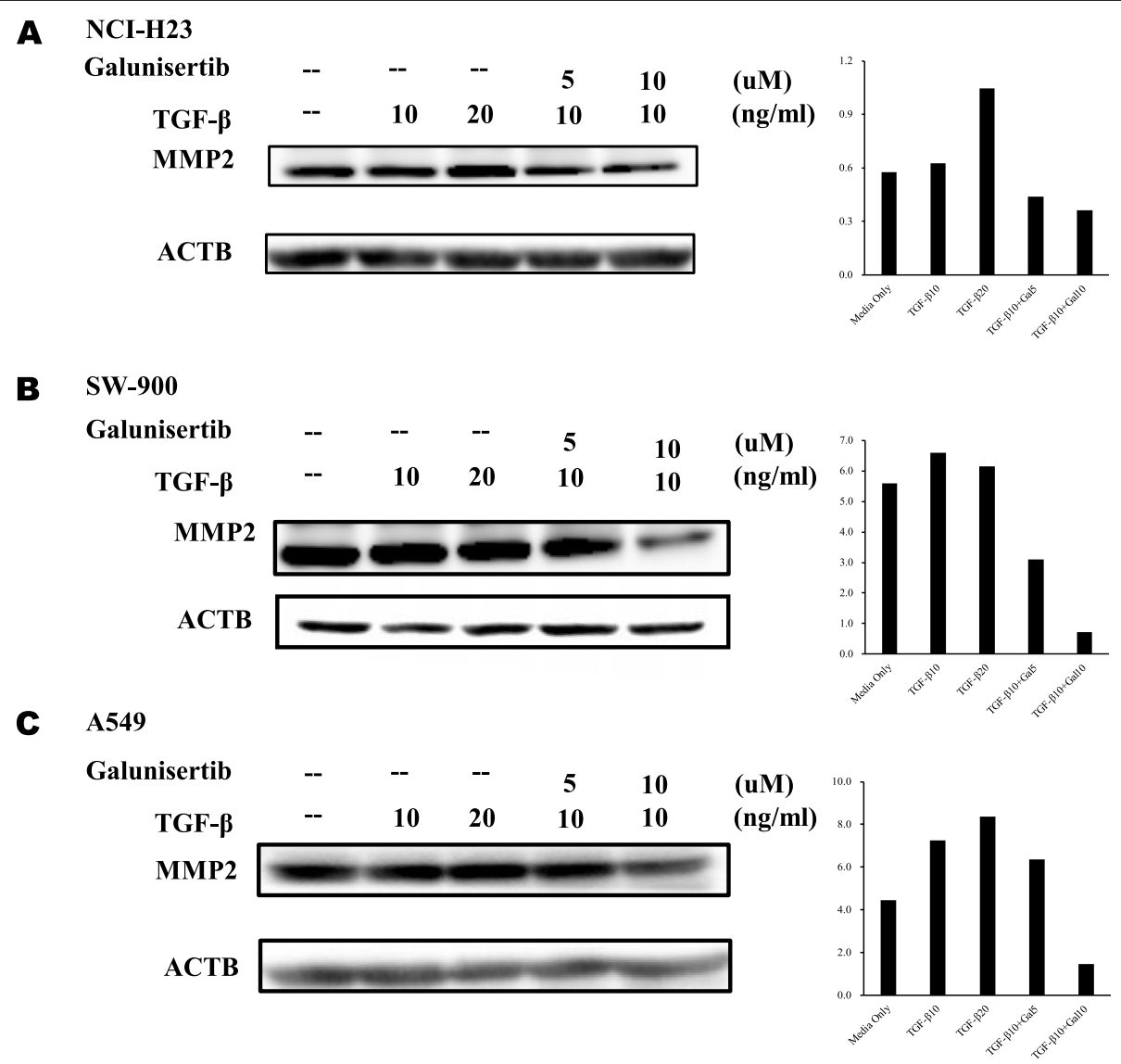

Fig. 5 The level of MMP2 was modulated by treatment with TGF- $\beta$ and Galunisertib. The MMP2 at protein level were analyzed in (A) NCl-H23, (B) SW-900 and (C) A549 lung cancer cells by western blot. Lung cancer cells were treated with TGF- $\beta$ (10 and 20 ng/ml) and Galunisertib (5 and $10 \mu \mathrm{M}$ ) for $18 \mathrm{~h}$. Bands were cropped from original images (Fig. S4) and intensity was measured using the ImageJ software and the expression levels were calculated by ratio against $\beta$-actin. The experiments were performed three times and showed representative data 

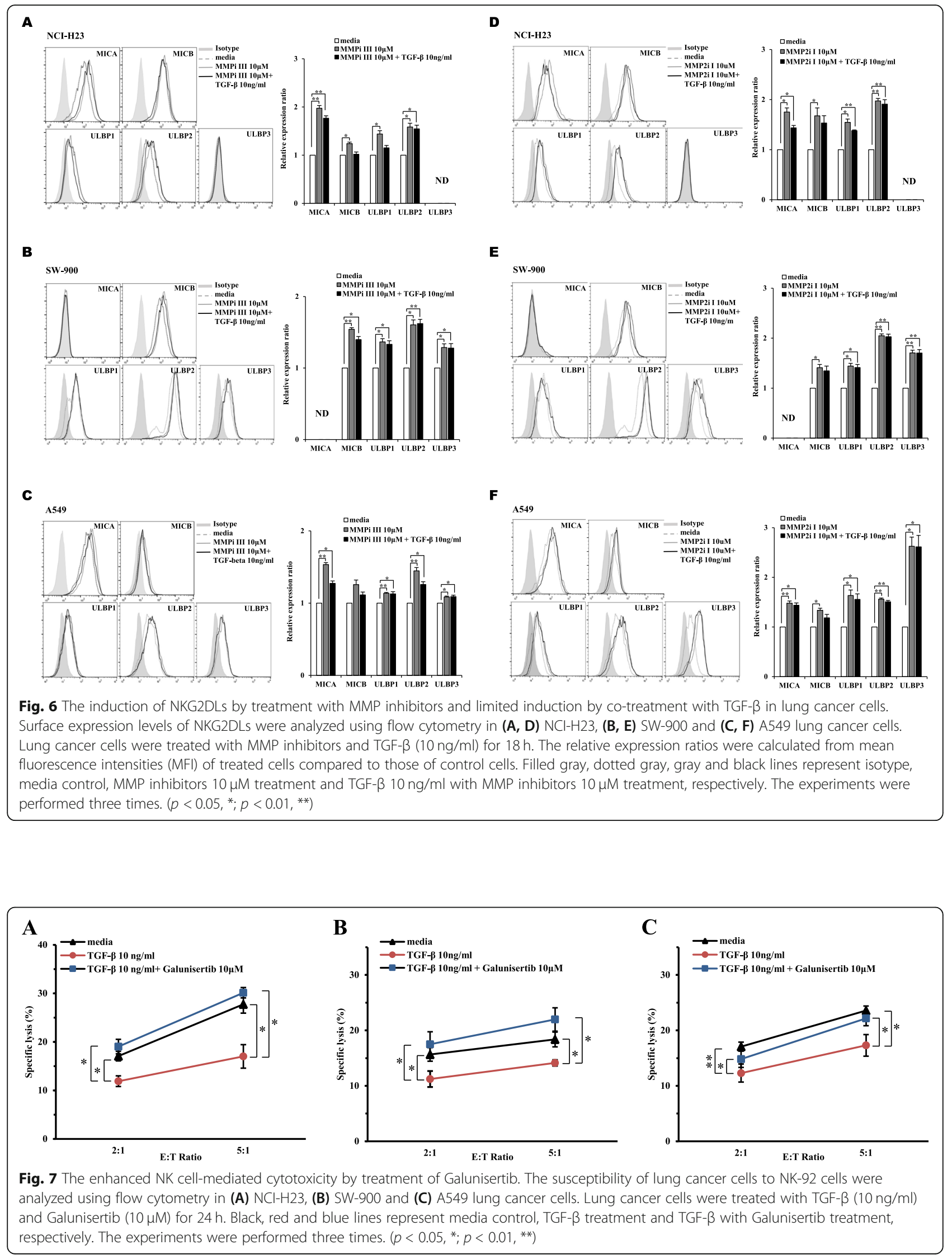
signaling, Beverly, MA; MMP9: Santa Cruz Biotechnology, Santa Cruz, CA, USA) and with horseradish peroxidase (HRP)-conjugated secondary antibodies (Cell Signaling Technology, MA, USA) using an enhanced chemiluminescence detection system (Amersham ${ }^{\mathrm{Tx}}$ ECL $^{\mathrm{rax}}$ Select Western Blotting Detection Reagent; GE Healthcare) in accordance with the manufacturer's instructions. Each blot was probed with an anti- $\beta$-actin antibody (Sigma-Aldrich, St. Louis, MO, USA). Bands were detected using AI 680 (Amersham ${ }^{\text {Tw }}$ Imager 680 - Blot and Gel Imager, GE Healthcare) and intensity quantification was performed using the ImageJ software (version 1.52; National Institutes of Health, Bethesda, MD, USA). The protein expressions in the treated cells were divided by the level of $\beta$-actin to calculate relative protein expression ratios.

\section{NK cell-mediated cytotoxicity}

NK cell mediated cytotoxicity was determined using FC500 flow cytometer (Beckman Coulter, CA, USA). The lung cancer cells were stained with $50 \mathrm{mM}$ carboxyfluorescein succinimidyl ester (CFSE) for $30 \mathrm{~min}$ at $37^{\circ} \mathrm{C}$ and washed three times. NK 92 cells and CFSE stained lung cancer cells were co cultured for $4 \mathrm{~h}$. Propidium iodide (PI) was added to the co cultured samples for identification of the dead cells. Cytotoxicity were calculated by formula of (CFSE+PI+ cells / CFSE+ cells) X 100 (\%).

\section{Statistical analysis}

To evaluate the altered gene expression levels, the mean folds of gene expressions among the groups and the standard error of the mean were calculated. For comparisons of the groups, a paired Student's t-test was performed. The analysis was performed using the SPSS statistical package (version 14.0; SPSS Inc., IL, USA). $P<0.05$ indicates a statistically significant difference in all of the experiments.

\section{Abbreviations}

EMT: Epithelial-mesenchymal transition; MFI: Mean fluorescence intensities; MIC: MHC class 1 chain-related protein; MMP: Matrix metalloproteinase; ND: Not detected; NKG2D: Natural-killer group2, member D; PD-L1/ 2: Programmed death ligand 1/2; TGF- $\beta$ : Transforming growth factor beta; ULBP: UL16 binding protein

\section{Supplementary Information}

The online version contains supplementary material available at https:/doi. org/10.1186/s12865-021-00434-8.

Additional file 1: Fig. S1 The direct effect of Galunisertib to the expression of NKG2D ligands on lung cancer cells; A NCl-H23, B SW-900, and $\mathbf{C}$ A549. Fig. S2 The expression of PD-L1/2 on lung cancer cells; $\mathbf{A}$ $\mathrm{NCl}-\mathrm{H} 23$, B SW-900, and C A549. Fig. S3 The expression of ADAM10 and ADAM17 after TGF- $\beta$ and Galunisertib treatment. A NCl-H23 cells; B SW900 cells; C A549 cells. Figures4 The modulation of MMP2 by TGF- $\beta$ and
Galunisertib treatment. A MMP2 and actin in NCI-H23 cells; B MMP2 and actin in SW-900 cells; C MMP2 and actin in A549 cells.

\section{Acknowledgements}

Not applicable.

\section{Authors' contributions}

YSL wrote and edited the manuscript. HJC performed experiments and wrote original draft. HRC performed experiments. WCS performed statistical analysis. YSP analyzed experimental data. CDK developed the platform of multiplex PCR for NKG2DLs. JB designed and evaluated the study. All the authors read and approved the final version.

\section{Funding}

This work was supported by the Financial Supporting Project of Long-term Overseas Dispatch of PNU's Tenure-track Faculty, 2016, and the National Research Foundation of Korea (NRF) grant funded by the Korea government, Ministry of Science and ICT (MSIT) (No. NRF-2018R1D1A1B07047437).

\section{Availability of data and materials}

The datasets used and/or analyzed during the current study are available from the corresponding author on reasonable request.

\section{Declarations}

Ethics approval and consent to participate

Not applicable.

\section{Consent for publication}

Not applicable.

\section{Competing interests}

The authors declare that they have no competing interests.

\section{Author details}

'Department of Biochemistry, Pusan National University School of Medicine, Yangsan 50162, South Korea. ${ }^{2}$ PNU BK21 Plus Biomedical Science Education Center, Pusan National University School of Medicine, Yangsan 50612, South Korea. ${ }^{3}$ Department of Research Center, Dongnam Institute of Radiological and Medical Sciences, Gijang, Busan 46033, South Korea.

Received: 6 October 2020 Accepted: 7 June 2021

Published online: 12 July 2021

\section{References}

1. Ferlay J, Soerjomataram I, Dikshit R, Eser S, Mathers C, Rebelo M, et al. Cancer incidence and mortality worldwide: sources, methods and major patterns in GLOBOCAN 2012. Int J Cancer. 2015;136(5):E359-86. https://doi. org/10.1002/ijc.29210.

2. Schmittel A, Sebastian M, Fischer von Weikersthal L, Martus P, Gauler TC, Kaufmann C, et al. A German multicenter, randomized phase III trial comparing irinotecan-carboplatin with etoposide-carboplatin as first-line therapy for extensive-disease small-cell lung cancer. Ann Oncol. 2011;22(8): 1798-804. https://doi.org/10.1093/annonc/mdq652.

3. Jotte R, Conkling P, Reynolds C, Galsky MD, Klein L, Fitzgibbons JF, et al. Randomized phase II trial of single-agent amrubicin or topotecan as second-line treatment in patients with small-cell lung cancer sensitive to first-line platinum-based chemotherapy. J Clin Oncol. 2011;29(3):287-93. https://doi.org/10.1200/JCO.2010.29.8851.

4. Jamieson AM, Diefenbach A, McMahon CW, Xiong N, Carlyle JR, Raulet DH. The Role of the NKG2D Immunoreceptor in Immune Cell Activation and Natural Killing. Immunity. 2004;20(6):799.

5. Nausch N, Cerwenka A. NKG2D ligands in tumor immunity. Oncogene. 2008;27(45):5944-58. https://doi.org/10.1038/onc.2008.272.

6. Ohaegbulam KC, Assal A, Lazar-Molnar E, Yao Y, Zang X. Human cancer immunotherapy with antibodies to the PD-1 and PD-L1 pathway. Trends Mol Med. 2015;21(1):24-33. https://doi.org/10.1016/j.molmed.2014.10.009.

7. Hsu J, Hodgins JJ, Marathe M, Nicolai CJ, Bourgeois-Daigneault MC, Trevino TN, et al. Contribution of NK cells to immunotherapy mediated by PD-1/PD- 
L1 blockade. J Clin Invest. 2018;128(10):4654-68. https://doi.org/10.1172/ JCl99317.

8. Wrzesinski SH, Wan YY, Flavell RA. Transforming growth factor-beta and the immune response: implications for anticancer therapy. Clin Cancer Res. 2007;13(18 Pt 1):5262-70. https://doi.org/10.1158/1078-0432.CCR-07-1157.

9. Derynck R, Akhurst RJ, Balmain A. TGF-beta signaling in tumor suppression and cancer progression. Nat Genet. 2001;29(2):117-29. https://doi.org/10.103 8/ng1001-117.

10. Xue XY, Zhao S, Zhang ZN, Wang YM, Chang Y, Xu YL, et al. The relationship of transforming growth factor-beta and lung cancer. Int J Clin Exp Med. 2016;9(6):9766-80.

11. Hasegawa Y, Takanashi S, Kanehira Y, Tsushima T, Imai T, Okumura K. Transforming growth factor-betal level correlates with angiogenesis, tumor progression, and prognosis in patients with nonsmall cell lung carcinoma. Cancer. 2001;91(5):964-71. https://doi.org/10.1002/1097-0142(20010301)91: 5<964::AID-CNCR1086>3.0.CO;2-O.

12. Castriconi R, Cantoni C, Della Chiesa M, Vitale M, Marcenaro E, Conte R, et al. Transforming growth factor beta 1 inhibits expression of NKp30 and NKG2D receptors: consequences for the NK-mediated killing of dendritic cells. Proc Natl Acad Sci U S A. 2003;100(7):4120-5. https://doi.org/10.1073/ pnas.0730640100.

13. Friese MA, Wischhusen J, Wick W, Weiler M, Eisele G, Steinle A, et al. RNA interference targeting transforming growth factor-beta enhances NKG2Dmediated antiglioma immune response, inhibits glioma cell migration and invasiveness, and abrogates tumorigenicity in vivo. Cancer Res. 2004;64(20): 7596-603. https://doi.org/10.1158/0008-5472.CAN-04-1627.

14. Bodmer S, Strommer K, Frei K, Siepl C, de Tribolet N, Heid I, et al. Immunosuppression and transforming growth factor-beta in glioblastoma. Preferential production of transforming growth factor-beta 2. J Immunol. 1989;143(10):3222-9.

15. Leitlein J, Aulwurm S, Waltereit R, Naumann U, Wagenknecht B, Garten W, et al. Processing of immunosuppressive pro-TGF-beta 1,2 by human glioblastoma cells involves cytoplasmic and secreted furin-like proteases. I Immunol. 2001; 166(12):7238-43. https://doi.org/10.4049/jimmunol.166.12.7238.

16. Pasche B. Role of transforming growth factor beta in cancer. J Cell Physiol. 2001;186(2):153-68. https://doi.org/10.1002/1097-4652(200002)186:2<153::A ID-JCP1016>3.0.CO;2-J.

17. Sun L, Diamond ME, Ottaviano AJ, Joseph MJ, Ananthanarayan V, Munshi HG. Transforming growth factor-beta 1 promotes matrix metalloproteinase9-mediated oral cancer invasion through snail expression. Mol Cancer Res. 2008;6(1):10-20. https://doi.org/10.1158/1541-7786.MCR-07-0208.

18. Kim ES, Kim MS, Moon A. TGF-beta-induced upregulation of MMP-2 and MMP-9 depends on P38 MAPK, but not ERK signaling in MCF10A human breast epithelial cells. Int J Oncol. 2004;25(5):1375-82.

19. Shiraishi K, Mimura K, Kua LF, Koh V, Siang LK, Nakajima S, et al. Inhibition of MMP activity can restore NKG2D ligand expression in gastric cancer, leading to improved NK cell susceptibility. J Gastroenterol. 2016:51(12):1101-11. https://doi.org/10.1007/s00535-016-1197-X.

20. Zingoni A, Cecere F, Vulpis E, Fionda C, Molfetta R, Soriani A, et al. Genotoxic stress induces senescence-associated ADAM10-dependent release of NKG2D MIC ligands in multiple myeloma cells. J Immunol. 2015; 195(2):736-48. https://doi.org/10.4049/jimmunol.1402643.

21. Chitadze G, Lettau M, Bhat J, Wesch D, Steinle A, Furst D, et al. Shedding of endogenous MHC class I-related chain molecules a and B from different human tumor entities: heterogeneous involvement of the "a disintegrin and metalloproteases" 10 and 17. Int J Cancer. 2013;133(7):1557-66. https://doi. org/10.1002/ijc.28174.

22. Saito A, Horie M, Nagase T. TGF-beta Signaling in Lung Health and Disease. Int J Mol Sci. 2018;19(8):2460

23. Sun D, Wang X, Zhang H, Deng L, Zhang Y. MMP9 mediates MICA shedding in human osteosarcomas. Cell Biol Int. 2011;35(6):569-74. https://doi.org/1 0.1042/CBI20100431.

24. Liu G, Atteridge CL, Wang X, Lundgren AD, Wu JD. The membrane type matrix metalloproteinase MMP14 mediates constitutive shedding of MHC class I chain-related molecule a independent of a disintegrin and metalloproteinases. J Immunol. 2010;184(7):3346-50. https://doi.org/10.4049/ jimmunol.0903789.

25. Li H, He G, Yao H, Song L, Zeng L, Peng $X$, et al. TGF-beta induces degradation of PTHrP through ubiquitin-proteasome system in hepatocellular carcinoma. J Cancer. 2015;6(6):511-8. https://doi.org/10.7150/ jca.10830.
26. Terme JM, Lhermitte L, Asnafi V, Jalinot P. TGF-beta induces degradation of TAL1/SCL by the ubiquitin-proteasome pathway through AKT-mediated phosphorylation. Blood. 2009;113(26):6695-8. https://doi.org/10.1182/ blood-2008-07-166835.

27. Trinh TL, Kandell WM, Donatelli SS, Tu N, Tejera MM, Gilvary DL, et al. Immune evasion by TGFbeta-induced miR-183 repression of MICA/B expression in human lung tumor cells. Oncoimmunology. 2019;8(4): e1557372. https://doi.org/10.1080/2162402X.2018.1557372.

28. Syed V. TGF-beta signaling in Cancer. J Cell Biochem. 2016;117(6):1279-87. https://doi.org/10.1002/jcb.25496.

29. Kopp HG, Placke T, Salih HR. Platelet-derived transforming growth factorbeta down-regulates NKG2D thereby inhibiting natural killer cell antitumor reactivity. Cancer Res. 2009;69(19):7775-83. https://doi.org/10.1158/0008-54 72.CAN-09-2123.

30. Trapani JA. The dual adverse effects of TGF-beta secretion on tumor progression. Cancer Cell. 2005;8(5):349-50. https://doi.org/10.1016/j.ccr.2 005.10.018.

31. Shevach EM. Mechanisms of foxp3+ T regulatory cell-mediated suppression. Immunity. 2009;30(5):636-45. https://doi.org/10.1016/j.jmmuni.2009.04.010.

32. Nakamura K, Kitani A, Strober W. Cell contact-dependent immunosuppression by CD4(+)CD25(+) regulatory T cells is mediated by cell surface-bound transforming growth factor beta. J Exp Med. 2001;194(5): 629-44. https://doi.org/10.1084/jem.194.5.629.

33. Ghiringhelli F, Menard C, Terme M, Flament C, Taieb J, Chaput N, et al. $\mathrm{CD} 4+\mathrm{CD} 25+$ regulatory $T$ cells inhibit natural killer cell functions in a transforming growth factor-beta-dependent manner. J Exp Med. 2005; 202(8):1075-85. https://doi.org/10.1084/jem.20051511.

34. Eisele G, Wischhusen J, Mittelbronn M, Meyermann R, Waldhauer I, Steinle A, et al. TGF-beta and metalloproteinases differentially suppress NKG2D ligand surface expression on malignant glioma cells. Brain. 2006;129(Pt 9):2416-25. https://doi.org/10.1093/brain/awl205.

35. Bellone G, Aste-Amezaga M, Trinchieri G, Rodeck U. Regulation of NK cell functions by TGF-beta 1. J Immunol. 1995;155(3):1066-73.

36. Wiercinska E, Naber HP, Pardali E, van der Pluijm G, van Dam H, ten Dijke P. The TGF-beta/Smad pathway induces breast cancer cell invasion through the up-regulation of matrix metalloproteinase 2 and 9 in a spheroid invasion model system. Breast Cancer Res Treat. 2011;128(3):657-66. https:// doi.org/10.1007/s10549-010-1147-x.

37. Malaponte G, Zacchia A, Bevelacqua Y, Marconi A, Perrotta R, Mazzarino MC, et al. Co-regulated expression of matrix metalloproteinase-2 and transforming growth factor-beta in melanoma development and progression. Oncol Rep. 2010;24(1):81-7. https://doi.org/10.3892/or_ 00000831.

38. Krstic J, Santibanez JF. Transforming growth factor-beta and matrix metalloproteinases: functional interactions in tumor stroma-infiltrating myeloid cells. ScientificWorld Journal. 2014;2014:521754.

39. Huang BC, Sikorski R, Sampath P, Thorne SH. Modulation of NKG2D-ligand cell surface expression enhances immune cell therapy of Cancer. I Immunother. 2011;34(3):289-96. https:/doi.org/10.1097/Cl.0b013e31820e1 b0d.

40. Duan $S$, Guo $W, X u Z$, He $Y$, Liang $C$, Mo $Y$, et al. Natural killer group $2 D$ receptor and its ligands in cancer immune escape. Mol Cancer. 2019;18(1): 29. https://doi.org/10.1186/s12943-019-0956-8.

41. Chitadze G, Bhat J, Lettau M, Janssen O, Kabelitz D. Generation of soluble NKG2D ligands: proteolytic cleavage, exosome secretion and functional implications. Scand J Immunol. 2013;78(2):120-9. https://doi.org/10.1111/ sji.12072.

42. Benson DM Jr, Bakan CE, Zhang S, Collins SM, Liang J, Srivastava S, et al. IPH2101, a novel anti-inhibitory KIR antibody, and lenalidomide combine to enhance the natural killer cell versus multiple myeloma effect. Blood. 2011; 118(24):6387-91. https://doi.org/10.1182/blood-2011-06-360255.

43. Delgado DC, Hank JA, Kolesar J, Lorentzen D, Gan J, Seo S, et al. Genotypes of NK cell KIR receptors, their ligands, and Fcgamma receptors in the response of neuroblastoma patients to Hu14.18-IL2 immunotherapy. Cancer Res. 2010;70(23):9554-61. https://doi.org/10.1158/0008-5472.CAN-10-2211.

44. Ljunggren HG, Malmberg KJ. Prospects for the use of NK cells in immunotherapy of human cancer. Nat Rev Immunol. 2007;7(5):329-39. https://doi.org/10.1038/nri2073.

45. Waldhauer I, Steinle A. NK cells and cancer immunosurveillance. Oncogene. 2008;27(45):5932-43. https://doi.org/10.1038/onc.2008.267.

46. Lee YS, Heo W, Nam J, Jeung YH, Bae J. The combination of ionizing radiation and proteasomal inhibition by bortezomib enhances the 
expression of NKG2D ligands in multiple myeloma cells. J Radiat Res. 2018; 59(3):245-52. https://doi.org/10.1093/jrr//ry005.

47. Park SW, Bae JH, Kim SD, Son YO, Kim JY, Park HJ, et al. Comparison of level of NKG2D ligands between normal and tumor tissue using multiplex RTPCR. Cancer Investig. 2007;25(5):299-307. https://doi.org/10.1080/073 57900701208824.

48. Lee YS, Heo W, Son CH, Kang CD, Park YS, Bae J. Upregulation of Myc promotes the evasion of NK cellmediated immunity through suppression of NKG2D ligands in K562 cells. Mol Med Rep. 2019;20(4):3301-7. https://doi. org/10.3892/mmr.2019.10583.

\section{Publisher's Note}

Springer Nature remains neutral with regard to jurisdictional claims in published maps and institutional affiliations.

Ready to submit your research? Choose BMC and benefit from:

- fast, convenient online submission

- thorough peer review by experienced researchers in your field

- rapid publication on acceptance

- support for research data, including large and complex data types

- gold Open Access which fosters wider collaboration and increased citations

- maximum visibility for your research: over $100 \mathrm{M}$ website views per year

At $\mathrm{BMC}$, research is always in progress.

Learn more biomedcentral.com/submissions 